\title{
Relationships among Teachers' Justice and Cynicism Perceptions and Political Influence Behaviours of School Principals
}

\author{
Beyza HIMMETOĞLU ${ }^{1}$, Damla AYDUĞ ${ }^{2}$, Coşkun BAYRAK ${ }^{3}$ \\ ${ }^{1}$ Department of Educational Sciences, Anadolu University, ORCID ID: 0000-0003-0757-232X \\ Email: beyzahimmetoglu@anadolu.edu.tr \\ 2 Department of Educational Sciences, Anadolu University, ORCID ID: 0000-0001-8348-5098 \\ Email: damlaaydug@anadolu.edu.tr \\ ${ }^{3}$ Department of Educational Sciences, Anadolu University, ORCID ID: 0000-0001-5524-5206 \\ Email: cbayrak@anadolu.edu.tr
}

\begin{abstract}
Main purpose of this study is to examine the effects of teachers' organizational justice perceptions and the political behaviours used by school principals on teachers' organizational cynicism levels according to the opinions of primary school teachers. Sample of study, designed as a correlational study, consisted of 614 primary school teachers selected via cluster sampling method among 1948 primary school teachers. According to results, organizational cynicism levels of teachers are low. According to teachers' opinions, the most preferred political influence behaviours of school principals is idealized effect and the least one is pressure. Results show that organizational justice perceptions of teachers are high. Lastly, results of the study indicate that organizational justice perceptions of teachers and their opinions on the idealized effect and pressure behaviours used by school principals predict about $\% 41$ of their organizational cynicism levels. While organizational justice perceptions of teachers and idealized effect behaviour used by school principals predict organizational cynicism levels of teachers negatively, pressure behaviour used by school principals predicts it positively. With the scope of these results, some suggestions were made to decrease of organizational cynicism levels of teachers and for further researches.
\end{abstract}

Key words: Organizational cynicism, political behaviours, organizational justice perception, primary school teachers.

\section{Introduction}

Studies aiming effectiveness and productiveness of organizations try to examine the functional and unfunctional behaviours of these individuals. These studies constituting the literature of organizational behaviour field not only try to enhance positive behaviours in the organization but also try to help developing strategies to prevent negative behaviours by identifying this kind of behaviours. One of these negative and harmful behaviours of members is organizational cynicism that has taken attention since 1980 's in the organizational behaviour literature.

Examination of factors, which affect organizational cynicism positively or negatively, can help taking precautions to protect the organization. It is especially crucial to emphasize organizational cynicism for educational organizations since correcting the mistakes or deficiencies of their products is nearly impossible, basic inputs and outputs of them are people. Avoiding from negative consequences of organizational cynicism is only possible with minimizing the prevalence of organizational cynicism around the school environment. The first step of doing this is to define the antecedents of organizational cynicism. So, this study aims to identify some antecedents of organizational cynicism at educational organizations and contribute the effectiveness of these organizations.

In educational organizations, number of studies examining organizational cynicism has started to increase since 2000's. These studies have examined the relationships between organizational cynicism and such variables as school culture (Karadağ, Kılıçoğlu, \& Yllmaz, 2014), job satisfaction (Arabacı, 2010), leadership behaviours (Polatcan \& Titrek, 2014), professionalism (Altınkurt \& Ekinci, 2016), organizational trust (Akın, 2015), and power sources of school principals (Altınkurt et al., 2014). Besides, one of the most commonly examined variables for the relationships with organizational cynicism is organizational justice both in general organization literature and specifically in the literature of educational organizations (Bernerth et al., 2007; Biswas \& Kapil, 2017; Chrobot-Mason, 2003; Efeoğlu \& İplik, 2011). Organizational justice perception is one of the variables examined in terms of its relationships with organizational cynicism in this study, too. Another variable examined in terms of its relationships with organizational cynicism in 
this study is usage of political behaviours by school principals. Literature suggests that organizational politics is among the important determinants of organizational cynicism (Davis \& Gardner, 2004). However, there are limited number of studies examining the relationships between organizational politics and organizational cynicism empirically (Bashir et al., 2011; Huang, Chuang, \& Lin, 2003; Konakl, 2016). Besides, number of studies examining the effects of organizational justice perceptions and organizational politics together on organizational cynicism is even less (Chiaburu et al, 2013; James, 2005). However, it is believed that identifying factors triggering organizational cynicism at educational organizations, which have a crucial role in shaping the future of society, is a necessity to decide which precautions should be taken.

\section{Theoretical Framework}

According to Dean, Brandes ve Dharwadkar (1996) cynicism studies could be based on five theoretical predecessors which also contribute to the conceptualization of organizational cynicism. These predecessors are classified as personality focus, occupational cynicism focus, societal/institutional focus, organizational change focus and employee cynicism focus. Among them, this study builds organizational cynicism concept's theoretical framework on employee cynicism focus. In employee cynicism focus, cynic behaviours are directed to organization in general, managers or principals of the organizational and the other people or things around the organization. This perspective makes it clear that cynicism of employees largely depends on the organizational and managerial processes and employees' perceptions about these processes. So, organizational cynicism in this study is based on mentioned employee cynicism focus and its antecedent are looked for among perceptions of teachers about organizational justice which is mostly shaped by school principals' treatments to them and political behaviours directed from school principals to them.

\section{Organizational cynicism}

The concept of organizational cynicism takes its roots from the concept of cynicism which is generally defined as believing that other people are dishonest, fraud, invaluable and selfish (Barefoot et al., 1989) or they are unreliable and politic (Graham, 1993 in Brandes, 1997). Cynicism has emerged as a philosophical worldview in Ancient Greek and has been used to characterize life styles of cynics since then (Brandes, 1997). Cynics have defended a virtuous life, full independence of people (Gokberk, 2005) and avoiding from pleasures of material life. Besides, they have underestimated and criticized public life and management (Weber, 1993). Examination of cynic behaviours of organization members has led the emergence of organizational cynicism concept in organizational behaviour literature.

Organizational cynicism is defined as harsh criticisms directed by members towards the organization explicitly or implicitly, and negative believes or emotions of them for the organization. Based on this definition, organizational cynicism has been examined under three dimensions which are cognitive, affective and behavioural cynicisms (Dean, Brandes, \& Dharwadkar, 1998). Cognitive dimension contains negative believes of members about the organization. Affective dimension contains emotional reactions of individuals to the negative situations around the organization. Behavioural dimension contains negative actions of individuals around the organization (Dean, Brandes, \& Dharwadkar, 1998). Such a thought which claims that organizational cynicism related with negative emotions, thoughts and behaviours could cause negative outcomes in terms of effectiveness and efficiency and could have negative impacts on members of the organization indicates the necessity of emphasizing organizational cynicism concept (James, 2005). When negative organizational consequences of organizational cynicism are considered, it can be said that, organizations likely try to take precautions against organizational cynicism and try to decrease organizational cynicism levels of members. However, to achieve this, it is a necessity to define antecedents of organizational cynicism or the factors increasing organizational cynicism levels of members.

Organizational cynicism is generally shaped by experiences of individuals and affected from attitudes and behaviours of others around the organization rather than being a personal characteristic (James, 2005; Johnson \& O'Leary-Kelly, 2003). Studies also indicate that organizational cynicism does not only result from personal characteristics of individuals but also can be triggered by environmental factors and can change in time (Abraham, 2000; Dean, Brandes, \& Dharwadkar, 1998; Johnson \& O'Leary-Kelly, 2003). Abraham (2000) states that negative emotions and thoughts about the organization generally stem from the belief that the organization or members of the organizations lack of honesty, sincerity and fairness. Antecedent factors of organizational cynicism are examined under two titles which are personal and organizational 
factors. However, studies focusing on the relationships between organizational cynicism and personal factors are few in number (James, 2005). Studies examining the factors effecting organizational cynicism mostly focus on organizational factors. One the most important reasons of this situation is the reality that organizations can take precautions for organizational factors.

\section{Organizational justice}

Organizational justice is one of the mostly emphasized concepts in organizational behaviour literature. This is due to the fact that an organization member with high level of organizational justice perception generally have positive attitudes towards the organization, her/his job and superiors (Moorman, 1991). Organizational justice concept is rooted from Adam's (1965) equity theory, Homan's (1961) distributive justice theory and Stouffer and colleagues' (1949) relative deprivation theory (Greenberg, 1990). According to equity theory, justice perception is shaped with the comparisons of individuals' her/his own inputs, outputs with others' inputs, and outputs (Bernerth et al., 2007). According to distributive justice theory, if costs of a group member's higher, they should be rewarded higher (Homans, 1958). Similarly, relative deprivation theory is also related with the perceptions of not getting the rewards an individual believes to deserve because of her/his comparisons (Cho, Lee, \& Kim, 2014). These theories generally focus on the justice of outputs. However, researchers have focused on procedural and interactional dimension of organizational justice later on (Bernerth et al., 2007). So, organizational justice has been conceptualized as a variable which brings a new perspective to the field of organizational behaviour.

Organizational justice is not only about the outputs or rewards a person gets. It is also about the organizational processes and politics like promotion opportunities and interactions with managers and colleagues (Biswas \& Kapil, 2016). So, organizational justice is conceptualized with three dimensions which are distributive justice, procedural justice and interactional justice (Colquitt, Greenberg, \& Zapata-Phelan, 2005). Distributive justice is mostly related with outputs people get from the organization (Folger \& Konovsky, 1989), especially economic gains (Cropanzano \& Ambrose, 2001). Like indicated in equity theory, distributive justice perceptions are shaped by organization members' comparisons of their own inputs such as performance, effort, training etc. and outputs such as salaries, promotion etc. with others' these kinds of inputs and outputs (İçerli, 2010). Procedural justice is related with how decisions about the distribution of resources are made (Folger \& Konovsky, 1989) and whether members participate in decision making processes about resource distributions (Greenberg, 1990). Unlike distributive justice, procedural justice focuses on socio-emotional gains. Interactional justice is related with the perceptions of organization member about the fairness of treatments they get from managers (Blakely, Andrews, \& Moorman, 2005; Cropanzano, Bowen, \& Gilliland, 2007).

Organizational justice basically consists of the perceptions of organization members on whether they have been treated fairly or not (Moorman, 1991). This indicates the subjectivity of organizational justice perception. Accordingly, it can be said that organizational justice is shaped by behaviours and attitudes of managers in organizations. Therefore, it is believed that organizational justice can be one of the important antecedents of organizational cynicism, which is affected from decisions, attitudes, implementations and interactions in the organization.

\section{Political behaviour}

Political behaviour is defined as a behaviour of an organization member to achieve individual goals by directing others regardless of ignoring organizational goals or not while exhibiting these behaviours which are generally not parts of her/his role in the organization (Farrel \& Peterson, 1982; İslamoğlu \& Börü, 2007). One of the most important conditions making a behaviour political is the intent of this behaviour (İscan, 2005). Regardless of activeness or passiveness of the behaviour or whether it gives any harm, any behaviour which is exhibited to serve the own goals of a person or attempts to protect own interests of this person is called as political behaviour. Behaviour of an organization member who adjusts to opinions of colleagues even when s/he doesn't agree to gain advantages such as maintaining group membership and taking a share from group's profits can be called as a politic behaviour. 
Studies examining the antecedents of political behaviours in organizations show that factors such as work environment, personal characteristics of organization members and particularly characteristics of organizational structure have impacts on usage of political behaviours (Bursall, 2008; Ferris \& Kacmar, 1992). These studies also indicate that specific factors such as centrality level of the organization, size of the organization, task and role ambiguity, roles and procedures are among the most important antecedents of political behaviour perceptions (Eisenhardt \& Bourgeois, 1988; Miller, Rutherford, \& Kolodinsky, 2008). Consequences of organizational politics, on the other hand, are generally related with job participation, organizational commitment, job satisfaction, organizational citizenship behaviour, organizational trust, organizational justice, organizational climate and culture (Çalışkan, 2006; Ertem, 2012; Ferris and Kacmar, 1992; Mehtap, 2011). Political behaviours are generally accepted as harmful for organizations. However, it is also stated that if these behaviours are used to meet both organizational goals and personal goals at maximum level, they can produce positive consequences, too (Mehtap, 2011).

Negativity or positivity of political behaviours could change according to type and frequency of political behaviours used in organization could affect the consequences of these behaviours and attitudes of members towards the organization (Karadal, 2008; Yukl, Falbe, \& Youn, 1993). For example; while hard political behaviours as assertiveness, sanction, legitimating, blocking, or blaming others could result with negative consequences, soft political behaviours as rational persuasion, praising, inspiration, collaboration, consultation and personal appeal could result with positive consequences (Karadal, 2008; Kipnis \& Schmidt, 1988; Yukl \& Falbe, 1990).

Studies related to organizational politics generally examine the results of perceptions of organizational politics the effects of these perceptions on organizational behaviours. However, it is seen that number of studies examining the results of political behaviours is few in number. On the other hand, it is believed that examining the results of political behaviours and the effects of these behaviours on organizational behaviours and attitudes of members is crucial since these behaviours have impacts on perceptions of organizational politics, too. In this regard, it can be concluded that political behaviours are important factors shaping the attitudes and behaviours of members towards the organization and they can have impacts on organizational cynicism levels of members.

\section{Purpose and questions of the study}

Main purpose of this study is to examine the effects of teachers' organizational justice perceptions and opinions on political behaviours of school principals on their organizational cynicism levels. Based on this main purpose of the study, following research questions were posed:

(1) What is the organizational cynicism level of teachers?

(2) What are the opinions of teachers on political behaviours used by school principals?

(3) What are the organizational justice perceptions of teachers?

(4) Are organizational justice perceptions of teachers and political behaviours used by school principals statistically significant predictors of organizational cynicism levels of teachers?

\section{Method}

This quantitative research was designed with correlational research design. Correlational design is used to determine the co-change of two or more variables and the direction of this change (Creswell, 2021, p.21). Since this study aims to examine the relationships among of teachers' organizational justice perceptions, organizational cynicism levels and their opinions on political behaviours of school principals, correlational design is suitable for this study.

\section{Sampling}

The target population of the study consisted of 1948 teachers who work at primary schools affiliated with the Directorates of National Education in Tepebasi and Odunpazari in Eskisehir. While choosing the sample, cluster sampling method was used. Clusters in this study were determined as 44 schools in Tebepasi and 43 primary schools in Odunpazari. Accordingly, 25 primary schools from each cluster (Tepebasi and Odunpazari) were chosen and data collection tools were conducted to teachers. At the end of the data 
collection process, it was determined to include 614 data collection tools into the analysis. The necessary sample size representing the population with a $95 \%$ confidence level was calculated as 321 . So, it is decided that a sample of consisting of 614 primary school teachers is enough to represent the population. Demographic features of these teachers are presented in the Table 1.

Table 1. Demographic Features of Teachers

\begin{tabular}{llll}
\hline Variables & & f & $\mathbf{\%}$ \\
\hline Gender & Male & 168 & 27.3 \\
& Female & 444 & 72.1 \\
Age (year) & $21-30$ & 38 & 6.2 \\
& $31-40$ & 216 & 35.1 \\
Educational level & 41 and over & 362 & 58.8 \\
& Undergraduate degree & 54 & 8.8 \\
Seniority at school (years) & Graduate degree & 528 & 85.7 \\
& Postgraduate degree & 33 & 5.4 \\
& $1-8$ & 392 & 63.6 \\
& $9-16$ & 136 & 22.1 \\
& 17 and over & 88 & 14.3 \\
\hline
\end{tabular}

\section{Instrument}

Data of the study were collected via "Personal Information Form", "Organizational Cynicism Scale", "Political Influence Tactics Scale" and "Organizational Justice Scale". Personal information form consists of questions to identify gender, age, educational level and school seniority of teachers. Information related to scales are presented below:

Organizational Cynicism Scale: In the study, "Organizational Cynicism Scale", a 13-item scale, developed by Brandes, Dharwadkar and Dean (1999) was used. The scale consists of three dimensions which are cognitive, affective and behavioural cynicism. The scale was adopted to Turkish by Kalağan (2009). Linguistic equivalence, exploratory factor analysis and confirmatory factor analysis were used to determine the validity of the scale. To determine the reliability, on the other hand, internal consistency coefficients were calculated. When the reliability of the adopted scale was examined, internal consistency coefficients $(\alpha)$ are calculated as .93 for total of the scale, $.91, .95$ and 87 for dimensions respectively. To decide the validity of three-dimensioned structure of adopted scale, confirmatory factor analysis was used. According to result of this analysis, fit indexes of the scale are found as $\chi 2=137,23, \mathrm{sd}=61, \mathrm{p}<.001],((\chi 2 / \mathrm{sd})=2.25$, RMSEA=0.07, GFI=0.91, AGFI=0.87 (Kalağan, 2009). However, for the sample of this study, reliability and validity of the scale were re-examined. Accordingly, internal consistency coefficients $(\alpha)$ were calculated as .95 for total of the scale, .91 for cognitive dimension, .81 for affective dimension and .95 for behavioural dimension. As a result of confirmatory factor analysis, fit indices were found as $\left(x^{2} / \mathrm{sd}\right)=2.40$, RMSEA $=.087$, $\mathrm{CFI}=.96, \mathrm{TLI}=.95$, SRMR $=.057$ which are sufficient for good fit.

Political Influence Tactics Scale: In the study, "Political Influence Tactics Scale" originally developed by Yukl and Falbe (1990) and then revised by Berson and Sosik (2007) was used. Original scale had 44 items which define 11 political influence tactics. However, since this study examines the tactics directed from superiors to subordinates (from school principals to teachers), items related to tactics directed from subordinates to superiors were excluded and the scale form with 8 dimensions and 32 items was used. This was adopted to Turkish by Mehtap (2011). In this study, the scale form validity and reliability of which were re-examined by Author (2018) was preferred to use. After exploratory factor analysis, it was found that the scale consisted of 5 dimensions called as idealized effect, exchange, praise, legitimization and pressure and 30 items in the mentioned study. Internal consistency co-efficient values were calculated as $.96, .95, .93, .86$ and .83 respectively (Author, 2018). However, for the sample of this study, reliability and validity of the scale were re-examined. Accordingly, internal consistency coefficients $(\alpha)$ were calculated as $.94, .94, .92$, .83 and .83 respectively. As a result of confirmatory factor analysis, fit indices were found as $\left(x^{2} / \mathrm{sd}\right)=2.30$, RMSEA $=.084$, CFI=0.91, TLU=90, SRMR $=.059$ which are sufficient for good fit.

Organizational Justice Scale: In this study, "Organizational Justice Scale" prepared by Niehoff and Moorman (1993) and originally consisting of 20 items was used. The scale has three dimensions called as distributive 
justice, procedural justice and interactive justice. The scale was adopted to Turkish by Polat (2007) who also made the reliability and validity analysis of adopted scale form. After the exploratory factor analysis performed to determine the validity, a form with 19 items under 3 dimensions appeared. Internal consistency coefficients were calculated as .96 for total of the scale, .89 for distributive justice dimension, .95 for procedural justice dimension and .90 for interactional justice dimension (Polat, 2007). However, for the sample of this study, reliability and validity of the scale were re-examined. Internal consistency calculations to determine reliability and confirmatory factor analysis to determine validity were made. Accordingly, internal consistency coefficients $(\alpha)$ were calculated as . 96 for total of the scale, $.89, .94$ and .90 for dimensions respectively. As a result of confirmatory factor analysis, fit indices were found as $\left(\mathrm{x}^{2} / \mathrm{sd}\right)=$ 2.31, RMSEA $=.084$, CFI=.94 TLI=.92, SRMRS=.045 which are sufficient for good fit. So, it was decided that the scale is reliable and validate for the sample of this study.

\section{Data Analysis}

Distribution of data was examined with skewness and kurtosis coefficients. According to results of these normality test, it was decided that its distribution is normal. These results are presented in Table 2.

Table 3. Skewness and kurtosis values for research variables

\begin{tabular}{lccccc}
\hline Variable & No & Skewness & se & Kurtosis & Sd \\
\hline Organizational Cynicism & 614 & .534 & .099 & .686 & .197 \\
Cognitive Cynicism & 614 & .571 & .099 & .432 & .197 \\
Behavioral Cynicism & 614 & .153 & .099 & -.437 & .197 \\
Affective Cynicism & 614 & .974 & .099 & .912 & .197 \\
Idealized Effect & 614 & -.291 & .099 & .464 & .197 \\
Legitimization & 614 & -.526 & .099 & .868 & .197 \\
Praise & 614 & -.502 & .099 & .115 & .197 \\
Exchange & 614 & -.244 & .099 & -.785 & .197 \\
Pressure & 614 & .126 & .099 & -.471 & .197 \\
Organizational Justice & 614 & -.299 & .099 & .267 & .197 \\
Interactive Justice & 614 & -.413 & .099 & .165 & .197 \\
Distributive Justice & 614 & -.317 & .099 & .166 & 1.97 \\
Procedural Justice & 614 & -.363 & .099 & .237 & 1.97 \\
\hline
\end{tabular}

As seen Table 2, all of the skewness and kurtosis values calculated for research variables between -1 and +1 which are the suggested cut points for data normality. In order to answer the first three sub-questions of the study, descriptive statistics were used. In order to answer the last sub-question of the study, multiple regression analysis was used. But, before doing that, assumptions of multiple regression analysis were examined. In this sense, Mahalanobis distance was calculated as 15.60 under the value of 16.27 suggested for regression model with 3 independent variables (Pallant, 2007). In order to eliminate singularity assumption of regression analysis, correlation coefficients between variables were calculated. Since all correlation coefficients were under .70 suggested like by Pallant (2007), it was decided that singularity assumption was met. Then, to see whether there is multi-collinearity among independent variables, tolerance and VIF values were examined. It is suggested to be over .02 for tolerance value and under 10 for VIF value to avoid multi-collinearity (Myers, 1990, in Field, 2009). In the regression model of this study, the highest VIF value was calculated as 1.44 and the lowest tolerance value was calculated as .69. Lastly DurbinWatson value which is suggested to be between 1 and 3 (Field, 2009) was found as 1.77.

\section{Findings}

Firstly, minimum scores, maximum scores, means and standard deviations related to research variables were calculated as descriptive statistics. Related findings are presented in Table 3. 
Table 3. Descriptive Statistics for Teachers' Perceptions on Organizational Cynicism, Organizational Justice and Their Opinions on Political Behaviors of School Principals

\begin{tabular}{lcccccc}
\hline Variable & $\mathrm{N}$ & Item No & Min. & Max. & $\begin{array}{c}\overline{\mathrm{X}} / \text { Item } \\
\text { Number }\end{array}$ & $\begin{array}{c}\text { sd/Item } \\
\text { number }\end{array}$ \\
\hline Organizational Cynicism & 614 & 13 & 13.00 & 57.00 & 1.98 & 0.59 \\
Cognitive Cynicism & 614 & 5 & 5.00 & 22.00 & 2.14 & 0.73 \\
Behavioral Cynicism & 614 & 4 & 4.00 & 18.00 & 2.12 & 0.69 \\
Affective Cynicism & 614 & 4 & 4.00 & 17.00 & 1.64 & 0.68 \\
Idealized Effect & 614 & 14 & 34.00 & 70.00 & 4.03 & 0.51 \\
Legitimization & 614 & 4 & 4.00 & 20.00 & 3.78 & 0.66 \\
Praise & 614 & 4 & 4.00 & 20.00 & 3.69 & 0.78 \\
Exchange & 614 & 4 & 4.00 & 20.00 & 3.06 & 1.08 \\
Pressure & 614 & 4 & 4.00 & 20.00 & 2.70 & 0.93 \\
Organizational Justice & 614 & 19 & 40.00 & 95.00 & 4.04 & 0.57 \\
Interactive Justice & 614 & 4 & 8.00 & 20.00 & 4.20 & 0.62 \\
Distributive Justice & 614 & 6 & 12.00 & 30.00 & 4.03 & 0.61 \\
Procedural Justice & 614 & 9 & 17.00 & 45.00 & 3.97 & 0.63 \\
\hline
\end{tabular}

The first sub-question of the study is "What is the organizational cynicism level of teachers?". Analysis showed that teachers' answers to these items are in "Disagree" ( $\bar{x}=1.98, \mathrm{sd}=.59)$ category. So, it is concluded that organizational cynicism level of teachers is low. Results also indicate that cognitive cynicism level $(\bar{x}=2.14, \mathrm{sd}=.73)$, behavioral cynicism level $(\overline{\mathrm{x}}=2.12, \mathrm{sd}=.69)$ and affective cynicism level $(\overline{\mathrm{x}}=1.64, \mathrm{sd}=.68)$ of teachers are low, too. These results show that the lowest level organizational cynicism dimension is affective cynicism. Teachers' answers on this dimension is in the category of "Strongly disagree".

The second sub-question of the study is "What are the opinions of teachers on political behaviours used by school principals? Analysis showed that teachers' answers to these items show that the most frequently used political behaviour by school principals is idealized effect $(\bar{x}=4.03, \mathrm{sd}=.51)$. After idealized effect, school principals use legitimization $(\bar{x}=3.78, s d=.66)$ and praise $(\bar{x}=3.69, \mathrm{sd}=.78)$ behaviours frequently according to teachers' opinions. Answers of teachers for these three behaviours are in the category of "Agree". On the other hand, answers given to items of exchange $(\bar{x}=3.06, s d=1.08)$ and pressure $(\bar{x}=2.70$, $\mathrm{sd}=.93$ ) behaviours are in the category of "Neither agree nor disagree". So, it was determined that teachers think that the least frequently used political behaviour by school principals is pressure.

The third sub-question of the study is "What are the organizational justice perceptions of teachers?". Analysis showed that teachers' answers to these items were in "Agree" ( $\bar{x}=4.04$, sd=.57) category. So, it was concluded that organizational justice level of teachers was high. When the answers given to scale were examined for dimensions of organizational justice it was seen that teachers' perception of interactive justice $(\bar{x}=4.20, \mathrm{sd}=.62)$, distributive justice $(\overline{\mathrm{x}}=4.03, \mathrm{sd}=.61)$ and procedural justice $(\overline{\mathrm{x}}=3.97, \mathrm{sd}=.63)$ were high, too. Arithmetic means of these three dimensions were in the category of "Agree".

The last sub-question of the study is "Are organizational justice perceptions of teachers and political behaviours used by school principals statistically significant predictors of organizational cynicism levels of teachers?" To answer this question firstly correlation coefficients showing the relationships between variables were calculated and it was found that there were statistically significant relationships at low and medium levels between organizational cynicism and organizational justice (-.56), idealized effect $(-.48)$, pressure (.34), praise (-.31) and legitimization $(-.23)$. However, it was also found that there was not a statistically significant relationship between organizational cynicism and so, exchange behaviour was not included in regression analysis. While applying hierarchical regression analysis, independent variables were put in analysis according to their relationship levels with organizational cynicism from highest level to lowest level. The analysis showed that contributions of praise $(t=.35, p>05)$ and legitimization $(t=1.42$, $\mathrm{p}>.05$ ) which were put in analysis lastly were not statistically significant. So, the regression model used for results included organizational justice, idealized effect and pressure. Hierarchical regression analysis results are presented in Table 4. 
Table 4. Hierarchical Regression Analysis Results

\begin{tabular}{llllllllllc}
\hline Model & Variables & $\boldsymbol{B}$ & $\mathbf{S H}_{\mathbf{B}}$ & $\boldsymbol{\beta}$ & $\mathbf{t}$ & $\mathbf{p}$ & $\mathbf{R}^{2}$ & $\mathbf{A R}^{2}$ & $\mathbf{F}$ & $\mathbf{p}$ \\
\hline Model 1* & Justice & -.394 & .024 & -.556 & -16.56 & .000 & .31 & .31 & 274.40 & .000 \\
& & & & & & & & & & \\
Model 2* & Justice & -.300 & .028 & -.423 & -10.89 & .000 & .35 & .35 & 39.49 & .000 \\
& $\begin{array}{l}\text { Idealized } \\
\text { effect }\end{array}$ & -.262 & .042 & -.244 & -6.28 & .000 & & & & \\
Model 3* & & & & & & & & & \\
& $\begin{array}{l}\text { Justice } \\
\text { İdealized }\end{array}$ & -.275 & .026 & -.388 & -10.44 & .000 & .42 & .41 & 68.20 & .000 \\
& $\begin{array}{l}\text { effect } \\
\text { Pressure }\end{array}$ & .531 & .040 & -.236 & -6.40 & .000 & & & & \\
\hline
\end{tabular}

*Dependent variable is organizational cynicism.

When hierarchical regression analysis results are examined in Table 4, it is seen that the first model includes only organizational justice as independent variable. Accordingly, teachers' organizational justice perceptions predict about $31 \%\left(\Delta \mathrm{R}^{2}=.31\right)$ of their organizational cynicism levels statistically significantly. It is also seen that this prediction of organizational justice perceptions on organizational cynicism is negative, this means that as organizational justice perceptions of teachers increase their organizational cynicism levels decrease. In the second model, idealized effect behaviour of school principals was added in analysis as independent variable. This model shows that organizational justice perceptions and idealized effect behaviour predict about 35\% $\left(\Delta \mathrm{R}^{2}=.35\right)$ of teachers' organizational cynicism levels together. Also, it is seen that prediction of idealized effect on organizational cynicism is negative. In the last model, organizational justice, idealized effect and pressure were added in analysis as independent variables. These variables predict about $41 \%\left(\Delta \mathrm{R}^{2}=.41\right)$ of teachers' organizational cynicism levels together. However, usage of pressure behaviour by school principals predict teachers' organizational cynicism levels positively unlike other two variables.

\section{Results, Conclusions and Recommendations}

Results related to organizational cynicism levels of primary school teachers show that organizational cynicism are low. This result indicates that teachers have not negative believes and criticisms for the schools they work and they find their both the school and the school management fair and honest. Other studies conducted with teachers in Turkey also show that teachers' organizational cynicism levels are low (Akın, 2015; Korkut, 2019; Yıldız, 2013). Also, most of the studies examining organizational cynicism of teachers point out that teachers' affective cynicism levels are lower than other dimensions similar to this study's findings (Karadağ, Kılıçoğlu, \& Yılmaz, 2014; Özcan, 2014; Yıldız, 2013). Studies conducted in different countries have similar results for organizational cynicism levels of teachers, too (James, Miles, \& Mullins, 2011; Salanova et al., 2005; Simbula \& Guglielmi, 2010). These results imply that teachers trust their schools, school principals and colleagues and have positive emotions and behaviours towards them. The facts that teaching profession is prized in Turkish society and is an affectively fulfilling profession can be among the reasons why teachers' organizational cynicism levels are low. Besides, because of the centrality of Turkish educational system, many of the decisions are made at ministerial level and are implemented throughout the country. These also can be the reasons why teachers do not blame their schools for these decisions or implementations. The result of the study pointing the lowness of teachers' organizational cynicism levels can be interpreted as a highly positive situation in terms of teachers' contributions to the school goals and the future of the society.

Results indicate that the most frequently preferred political behaviour by school principals is idealized effect among political behaviours examined in this study. Idealized effect includes some influence tactics such as persuading others rationally, encouraging others to participate in decision making processes and taking others' needs and desires in consideration (Kipnis \& Schmidt, 1988; Yukl, Falbe, \& Youn 1993). These tactics are called as rational persuasion, consultation, inspiration and collaboration under the title of soft political influence behaviours (Yukl \& Tracey, 1992). On the other hand, results of the study indicate that the least frequently preferred political behaviour by school principals is pressure. While using this behaviour, people generally take actions such as insisting, threatening or controlling others tightly (Falbe \& Yukl, 1992). Most of the studies related to political behaviours of school principals have similar results 
with this study. Teachers generally think that their principals prefer soft political influence behaviours such as rational persuasion, consultation, collaboration, inspiration rather than hard ones such as making pressure (Aydın \& Pehlivan, 2010; Güleș, 2016; Somech \& Drach-Zahavy, 2002). While evaluating these results, it is possible to consider such factors that hierarchical bounds between the school principal and the teacher are loose and power distance is low. So, it is an expected result that school principals prefer soft political behaviours to direct teachers who are generally have similar educational degrees and similar expertise with the principals and they have autonomy in their classes. Also, preferring pressure could be so ineffective at schools like any other organization in which members are professionals. When these conditions are considered, the results indicating that school principals generally prefer to use idealized effect and avoid using pressure are highly expected ones.

Results related to organizational justice perceptions of teachers indicate that their organizational justice perceptions are high. Other similar studies also have shown that organizational justice perceptions of teachers are generally high (Baş \& Şentürk, 2011; Dipaola \& Guy, 2009; Malik \& Naeem, 2011; Zeinabadi \& Salehi, 2011). So, it is possible to interpret that teachers see managerial processes, behaviours of their principals and the outcomes they have in change of their efforts fair. When the dimensions of organizational justice considered, it is seen that interactive justice perceptions of teachers are higher. Other studies in the literature also indicate that interactive justice perceptions of teachers are higher than other dimensions (Altahayney, Khasawneh, \& Abedalhafiz, 2014; Babaoğlan \& Ertürk, 2013; Polat \& Kazak, 2014). This result of the study can be related to the fact that teaching profession constitutes the baseline of educational systems, it is the heart of schools. This also implies that being a school principal does not necessitate any further training and expertise other than being a teacher. So, it can be concluded that teachers do not perceive a distance between themselves and school principals which can create a communication barrier or a diversity in their worldviews. So, it is likely that their interactions include respect. Since their communication is generally open with principals, teachers can demand fair resource distribution or active participation in decision making processes.

Results of hierarchical regression analysis show organizational justice perceptions of teachers and usage of idealized effect and pressure behaviours by school principals are among statistically significant predictors of organizational cynicism levels of teachers. While idealized effect and organizational justice predict organizational cynicism negatively, pressure predicts organizational cynicism positively. Many studies in the literature also show that organizational justice is among the most important predictors of organizational cynicism (Bernerth et al., 2007; Chrobot-Mason, 2003; Köybaşı \& Uğurlu, 2017; Özgen \& Turunç, 2017). Since organizational cynicism is an employee attitude mostly shaped by organizational and managerial processes (Abraham, 2000), increase in organizational cynicism levels of teachers who think their organizational or principal is not fair can be accepted as natural result.

Impacts of micro-politics in organizations on employees' organizational cynicism levels are generally examined in the context of organizational politics perceptions in the literature. Some studies have results indicating that employees who find their organizations' politization level high, generally have high organizational cynicism levels, too. Therefore, organizational politics is accepted as an important antecedent of organizational cynicism (Al-Abrrow, 2018; Chiaburu et al., 2013; James, 2005). Results of this study also show that idealized effect is a negative predictor of organizational cynicism and pressure is a positive predictor of it. These results make explicit the responsibility of school principals in preventing organizational cynicism which influences effectiveness and development of schools badly. There are similar study results which show the effects of hard and soft principal behaviours on organizational cynicism. For example; there are such studies as indicating democratic leadership which includes participatory decisionmaking processes and ethical leadership which includes treating all organization member equally, fairly and honestly predict organizational cynicism negatively (İnce, 2018; Mete, 2013). Also, there exist positive relationships between coercive power of school principals and organizational cynicism levels of teachers (Altınkurt et al., 2014). Besides, some studies which examine organizational politics and organizational justice perceptions together as predictors of organizational cynicism like this study also assert that organizational cynicism is influenced from organizational processes mostly (Chiaburu et al., 2013; James, 2005). When the results of this study and other related studies in in the literature are considered, it is possible to say that communication between teachers and school principals is valued by teachers in a great extent and quality of this communication shape their perspectives towards the school. Expertise of teachers in their fields can be accepted as an important indicator of the fact that they cannot be effectively directed by giving orders or making pressure. Since teachers have a great control over their classes, it is possible that most of them feel themselves as owner of decisions and authority. So, it is crucial for school principals to appreciate teachers' expertise, value and respect them and evaluate their performance appropriately. By doing so, school principals would prefer behaviours included in idealized effect more rather than pressure 
and they would contribute in increase of organizational justice perceptions of teachers and so they would be able to prevent organizational cynicism among teachers.

Based on the results of this study some suggestions could be done for researchers and practitioners. Accordingly, it could be suggested that school principals should behave fairly while distributing resources, communicating with teachers and applying the rules to decrease organizational cynicism levels of teachers. Besides, when the current mechanism of Turkish educational system in which school principals and teachers have similar educational and expertise levels is considered, it could be suggested that school principals should prefer soft influence behaviours rather than making pressure while directing teachers. In this regard, it is believed assigning school principals who can use reference power more effectively, can change teachers' behaviours by inspiring them is a necessity. Also, these qualifications should be taken into consideration while training them. Lastly, it could be suggested that studies, supported semi-structured interviews, tending to examine the political behaviours of school political behaviours which contribute to decrease to decrease organizational cynicism levels of teachers should be conducted.

\section{References (APA 6)}

Abraham, R. (2000). Organizational cynicism: Bases and consequences. Genetic, Social, and General Psychology Monographs, 126(3), 269-292.

Akın, U. (2015). The relationship between organizational cynicism and trust in schools: A research on teachers. Education and Science, 40(181), 175-189.

AL-Abrrow, H.A. (2018). The effect of perceived organisational politics on organisational silence through organisational cynicism: Moderator role of perceived support.Journal of Management \& Organization, 1-20.

Altahayneh, Z.L., Khasawneh, A., \& Abedalhafiz, A. (2014). Relationship between organizational justice and job satisfaction as perceived by Jordanian physical education teachers. Asian Social Science, 10(4), 131.

Altınkurt, Y., \& Ekinci, C. E. (2016). Examining the relationships between occupational professionalism and organizational cynicism of teachers. Educational Process: International Journal, 5(3), 236-253.

Altınkurt, Y., Yllmaz, K., Erol, E., \& Salalı, E. T. (2014). Relationship between school principals' use of power sources and teachers' organizational cynicism perceptions. Journal of Teacher Education and Educators, 3(1), 25-52.

Apaydın, C.. (2012). Relationship between workplace bullying and organizational cynicism in Turkish public universities. African Journal of Business Management, 6(34), 9649-9657.

Arabaci, I.B. (2010). The effects of depersonalization and organizational cynicism levels on the job satisfaction of educational inspectors. African Journal of Business Management, 4(13), 2802-2811.

Author (2018). Removed for blind review.

Aydın, İ., \& Pehlivan, Z. (2010). Strategies and personality types used by primary school principals in Turkey to influence teachers (Ankara case). Procedia-Social and Behavioral Sciences, 2(2), 3652-3659.

Babaoğlan, E., \& Ertürk, E. (2013). Öğretmenlerin örgütsel adalet algısı ile örgütsel adanmışlıkları arasındaki ilişki [The relationship between teachers' organizational justice perception and organizational commitment]. Hacettepe University Journal of Education, 28(28-2), 87-101.

Barefoot, J.C., Dodge, K.A., Peterson, B.L., Dahlstrom, W.G., \& Williams, R.B. (1989). The Cook-Medley hostility scale: Item content and ability to predict survival. Psychosomatic Medicine, 51, 46-57.

Bashir, S., Nasir, Z.M., Saeed, S., \& Ahmed, M. (2011). Breach of psychological contract, perception of politics and organizational cynicism: Evidence from Pakistan. African Journal of Business Management, 5(3), 884-888.

Baş, G., \& Şentürk, C. (2011). İlköğretim okulu öğretmenlerinin örgütsel adalet, örgütsel vatandaşlık ve örgütsel güven algıları [Elementary school teachers' perceptions of organisational justice, organizational citizenship behaviours and organisational trust]. Educational Administration: Theory and Practice, 17(1), 29-62.

Bernerth, J.B., Armenakis, A.A., Feild, H.S., \& Walker, H.J. (2007). Justice, cynicism, and commitment: A study of important organizational change variables. The Journal of Applied Behavioral Science, 43(3), 303326.

Biswas, S., \& Kapil, K. (2017). Linking perceived organizational support and organizational justice to employees' in-role performance and organizational cynicism through organizational trust: A field investigation in India. Journal of Management Development, 36(5), 696-711.

Blakely, G.L., Andrews, M.C., \& Moorman, R.H. (2005). The moderating effects of equity sensitivity on the relationship between organizational justice and organizational citizenship behaviors. Journal of Business and Psychology, 20(2), 259-273. 
Brandes, P.M. (1997). Organizational cynicism: Its nature, antecedents, and consequences. Unpublished Doctoral Thesis, University of Cicinnati, Ohio.

Bursalı, Y.M. (2008). Örgütsel politikanın işleyişi: Örgütsel politika algısı ve politik davranış arasındaki ilişkiler [The functioning of organizastional politics: The relationships between perceptions of organizational politics and political behaviour]. Unpublished Doctoral Thesis, Dokuz Eylul University, Institute of Social Sciences, İzmir.

Çalışkan, K. (2006). Political behavior in organizations: Antecedents and consequences. Unpublished Doctoral Thesis, Marmara University, Institute of Social Sciences, İstanbul.

Chiaburu, D.S., Peng, A.C., Oh, I.S., Banks, G.C., \& Lomeli, L.C. (2013). Antecedents and consequences of employee organizational cynicism: A meta-analysis. Journal of Vocational Behavior, 83(2), 181-197.

Cho, B., Lee, D., \& Kim, K. (2014). How does relative deprivation influence employee intention to leave a merged company? The role of organizational identification. Human Resource Management, 53(3), 421-443.

Chrobot-Mason, D.L. (2003). Keeping the promise: Psychological contract violations for minority employees. Journal of Managerial Psychology, 18(1), 22-45.

Colquitt, J.A., Greenberg, J., \& Zapata-Phelan, C.P. (2005). What is organizational justice? A historical overview. J. Greenberg and J. A. Colquitt (Eds.). In Handbook of organizational justice (3-58), New Jersey: Lawrence Erlbaum Associates.

Cropanzano, R.C., \& Ambrose, M.L. (2001). Advances in organizational justice. J. Greenberg (Ed.). In Advances in organizational justice (119-151), Palo Alto: Stanford University Press.

Cropanzano, R., Bowen, D.E., \& Gilliland, S.W. (2007). The management of organizational justice. The Academy of Management Perspectives, 34-48.

Davis, W.D., \& Gardner, W.L. (2004). Perceptions of politics and organizational cynicism: An attributional and leader-member exchange perspective. The leadership quarterly, 15(4), 439-465.

Dean J.W., Brandes, P., \& Dharwadkar, R. (1998). Organizational cynicism. The Academy of Management Review, 23(2), 341-352.

Dipaola, M., \& Guy, S. (2009). The impact of organizational justice on climate and trust in high schools. Journal of School Leadership, 19(4), 382-405.

Efeoğlu, İ.E., \& İplik, E. (2011). Algılanan örgütsel adaletin örgütsel sinizm üzerindeki etkilerini belirlemeye yönelik ilaç sektöründe bir uygulama [A field research conducted to deterimne the effects of organizational justice perceptions on organizational cynicism in pharmaceutical industry]. Cukurova University Journal of Social Sciences, 20(3), 343-350.

Eisenhardt, K.M., \& Bourgeois III, L. J. (1988). Politics of strategic decision making in high velocity environments: Toward a midrange theory. The Academy of Management Journal, 31(4), 737-770.

Ertem, M. (2011). Örgüt kültürü ve politik davranış algılamaları: farklllıklar ve iliş̧kileri belirlemeye yönelik bir araştırma [Organizational culture and perceptions of political behaviour: A study to determine the differences and relations]. Unpublished Master's Thesis, Erciyes University, Institute of Social Sciences, Kayseri.

Farrel, D., \& Peterson, J. C. (1982). Patterns of political behavior in organizations. The Academy of Management Review, 7(3), 403-412.

Field, A. (2009). Discovering statistics using SPSS (and sex and drugs and rock ' $n$ ' roll). (Third Edition). London: SAGE.

Folger, R., \& Konovsky, M. A. (1989). Effects of procedural and distributive justice on reactions to pay raise decisions. Academy of Management Journal, 32(1), 115-130.

Gökberk, M. (2005). Felsefe tarihi [History of philosophy] (16th Edition). İstanbul: Remzi Kitabevi.

Greenberg, J. (1990). Organizational justice: Yesterday, today, and tomorrow. Journal of Management, 16(2), 399-432.

Güleş, H. (2016). Öğretmen görüşlerine göre okul yöneticilerinin ilişsi davranışları ve kullandıkları politik taktiklerin incelenmesi [Investigating school administrators' relationship behaviors and political tactics they use based on teacher views]. Unpublished Doctoral Thesis. Eskisehir Osmangazi University, Institute of Educational Sciences, Eskisehir.

Huang, I.C., Chuang, C.H.J., \& Lin, H.C. (2003). The role of burnout in the relationship between perceptions off organizational politics and turnover intentions. Public Personnel Management, 32(4), 519-531.

İçerli, L. (2010). Örgütsel adalet: Kuramsal bir yaklaşım [Organizational justice: A theoretical approach]. Journal of Entrepreneurship and Development, 5 (1), 67-92.

İnce, F. (2018). The effect of democratic leadership on organizational cynicism: A study on public employees. Journal of Business research-TURK, 10(2), 245-253.

İslamoğlu, G., \& Börü, D. (2007). Politik davranış boyutları: bir ölçek geliş̧irme çalışması [Scale development for the dimensions of political behavior]. Akdeniz IIBF Journal, 14, 135-153. 
İşcan, Ö. M. (2005). Siyasal arena metaforu olarak örgütler ve örgütsel siyasetin örgütsel adalet algısına etkisi [Organizations as politicall arena metaphors and the effect of organizational politics on the perception of organizational justice]. Ankara University SBF Journal, 60(1), 149-171.

Homans, G.C. (1958). Social behavior as exchange. American Journal of Sociology, 63(6), 597-606.

James, M.S.L. (2005). Antecedents and consequences of cynicism in organizations: An examination of the potential positive and negative effects on school systems. Unpublished Doctoral Thesis. The Florida State University, Florida.

James, M.S., Miles, A.K., \& Mullins, T. (2011). The interactive effects of spirituality and trait cynicism on citizenship and counterproductive work behaviors. Journal of Management, Spirituality \& Religion, 8(2), 165-182.

Johnson, J.L., \& O'Leary-Kelly, A.M. (2003). The effects of psychological contract breach and organizational cynicism: not all social exchange violations are created equal. Journal of Organizational Behavior, 24(5), 627-647.

Kalağan, G. (2009). Araştırma görevlilerinin örgütsel destek algıları ile örgütsel sinizm tutumları arasındaki ilişki [The relationship between researh assistants' perceived organizational support and organizational cynicism]. Unpublished Master's Thesis, Akdeniz University, Institute of Social Sciences, Ankara.

Karadag, E., Kilicoglu, G., \& Yilmaz, D. (2014). Organizational cynicism, school culture, and academic achievement: the study of structural equation modeling. Educational Sciences: Theory and Practice, 14(1), 102-113.

Karadal, H. (2008). Organizasyonlarda politik davranışlar ve taktikler [Political behaviors and tactics in organizations]. M. Özdevecioğlu and H. Karadal. (Eds). In Örgütsel davranışta seçme konular [Selected subjects in organizational behavior] (1-21), Ankara: İlke Yayincllı.

Kipnis, D., \& Schmidt, S. M. (1988). Upward influence styles: relationship with performance evaluations, salary, and stress. Administrative Science Quarterly, 33(4), 528-542.

Konakli, T. (2016). The effect of school administrators' political skills against organizational cynicism in educational organizations. Universal Journal of Educational Research, 4(3), 589-597.

Korkut, A. (2019). Ögrretmenlerin örgütsel mutluluk, örgütsel sinizm ve örgütsel adalet algılarının analizi [An analysis of teachers' perceptions of organizational happiness, organizational cynicism and organizational justice]. Unpublished Doctoral Thesis, Inonu University, Institute of Education, Malatya.

Köybaşı, F., Uğurlu, C.T., \& Öncel, A. (2017). Examining the relationship between teachers' organizational justice perceptions and organizational cynicism levels. Inonu University Journal of the Faculty of Education, 18(1), 01-14.

Malik, M.E., \& Naeem, B. (2011). Role of perceived organizational justice in job satisfaction: Evidence from higher education institutions of Pakistan. Interdisciplinary Journal of Contemporary Research in Business, 3(8), 662-673.

Mehtap, Ö. (2011). Örgüt içi politik davranışların örgütsel vatandaşlık davranışı üzerindeki etkisi [The effect of political behaviors on the organizational citizenship behavior]. Unpublished Doctoral Thesis, Istanbul University, Institute of Social Sciences, Istanbul.

Mete, Y.A. (2013). Relationship between organizational cynicism and ethical leadership behaviour: A study at higher education. Procedia-Social and Behavioral Sciences, 89, 476-483.

Moorman, R.H. (1991). Relationship between organizational justice and organizational citizenship behaviors: Do fairness perceptions influence employee citizenship? Journal of Applied Psychology, 76(6), 845.

Niehoff, B.P. \& Moorman, R.H. (1993). Justice as a mediator of the relationship between methods of monitoring and organizational citizenship behavior. Academy of Management Journal, 36(3), 527556.

Özcan, E. (2014). Öğretmenlerin örgütsel adalet algıları ile örgütsel sinizm tutumları arasındaki ilișki [The relationship between teachers' perceived organizational justice and organizational cynicism attitude]. Kocaeli Universitesi, Institute of Social Sciences, Kocaeli.

Özgen, F.Ö., \& Turunç, Ö. (2017). Örgütsel adalet-sinizm ilişkisinde kişi örgüt uyumunun rolü: Eğitim sektöründe bir araştırma [The role of person organization fit in the relationship of cynicism and organizational justice: A research in education sector]. Uluslararası İktisadi ve İdari Bilimler Dergisi [IJEAS], 3(2), 80-96.

Pallant, J. (2007). SPSS survival manual: A step by step guide to data analysis using SPSS. (3rd Edition). New York: McGraw Hill Open University Press.

Polat, S. (2007). Ortaöğretim öğretmenlerinin örgütsel adalet algılarl, örgütsel güven düzeyleri ile örgütsel vatandaşlık davranışları arasındaki ilişsi [Relation between organizational justice perceptions, 
organizational trust levels and organzational citizenship behaviors of secondary education teachers]. Published Doctoral Thesis, Kocaeli University, Institute of Social Sciences, Kocaeli.

Polat, S., \& Kazak, E. (2014). Okul yöneticilerinin kayırmacı tutum ve davranışları ile öğretmenlerin örgütsel adalet algıları arasındaki ilişki [The correlation between school principals' favoritist behaviors and attitudes and teachers' perception of organizational justice]. Educational Administration: Theory and Practice, 1(1), 71-92.

Polatcan, M., \& Titrek, O. (2014). The relationship between leadership behaviors of school principals and their organizational cynicism attitudes. Procedia-Social and Behavioral Sciences, 141, 1291-1303.

Salanova, M., Llorens, S., García-Renedo, M., Burriel, R., BresÓ, E., \& Schaufeli, W.B. (2005). Towards a fourdimensional model of burnout: A multigroup factor-analytic study including depersonalization and cynicism. Educational and Psychological Measurement, 65(5), 807-819.

Simbula, S., \& Guglielmi, D. (2010). Depersonalization or cynicism, efficacy or inefficacy: what are the dimensions of teacher burnout? European Journal of Psychology of Education, 25(3), 301-314.

Somech, A., \& Drach-Zahavy, A. (2002). Relative power and influence strategy: the effects of agent/target organizational power on superiors' choices of influence strategies. Journal of Organizational Behavior, 23(2), 167-179.

Ylldız, K. (2013). Örgütsel bağlllık ile örgütsel sinizm ve örgütsel muhalefet arasındaki ilişki [The relationship between organizational commitment and organizational cynicism and organizational dissent]. Turkish Studies-International Periodical for The Languages, Literature and History of Turkish or Turkic, 8(6), 853-879.

Yukl, G., \& Falbe, C.M. (1990). Influence tactics and objectives in upward, downward, lateral influence attempts. Journal of Applied Psychology, 75(2), 132-140.

Yukl, G., Falbe, C.M., \& Youn, J.Y. (1993). Patterns of influence behavior for managers. Group \& Organization Management, 18(1), 5-28.

Yukl, G., \& Tracey, J.B. (1992). Consequences of influence tactics used with subordinates, peers, and the boss. Journal of Applied Psychology, 77(4), 525.

Weber, A. (1993). Felsefe tarihi [History of philosophy]. (5 ${ }^{\text {th }}$ Edition). H. Vehbi Eralp. (Translator). Istanbul: Sosyal Yayınlar.

Zeinabadi, H., \& Salehi, K. (2011). Role of procedural justice, trust, job satisfaction, and organizational commitment in Organizational Citizenship Behavior (OCB) of teachers: Proposing a modified social exchange model. Procedia-Social and Behavioral Sciences, 29, 1472-1481. 